\title{
Knowledge of Sustainable Development Goal interactions for decision making - are current approaches fit for purpose?
}

Authors: Lorenzo Di Lucia* ac, Lars Nilsson ${ }^{b}$, Jamil Khan ${ }^{b}$ and Raphael Slade ${ }^{a}$

\author{
${ }^{a}$ Centre for Environmental Policy, Imperial College London, UK \\ ${ }^{\mathrm{b}}$ Environmental and Energy Systems Studies, Lund University, Sweden \\ c Physical Resource Theory, Chalmers University, Sweden \\ *Corresponding author: $\underline{\text { I.di-lucia@imperial.ac.uk }}$
}

Paper presented at the GlobalGoals2020 symposium (11 June 2020), Panel 4, Indicators and methods for Assessing Progress towards SDGs

\section{Summary}

Due to the interconnectedness of the SDGs, the potential to meet a specific goal is influenced by efforts to achieve other goals. To maintain the indivisibility of the 2030 Agenda, a growing number of approaches have been developed to provide knowledge of SDG interactions in the form of trade-offs and synergies. In this paper, we take stock of the rapid development, which has characterised the field, and conduct a critical review of the approaches available to support decision makers with the implementation of the UN Agenda. Our overall ambition is to provide a broad understanding of the support provided by existing methodologies to decision makers in light of the challenges emerging from the interconnected nature of the SDGs.

To achieve the aim of the study, we elect three specific objectives: (a) identify and categorise the most prominent approaches available for understanding SDG interactions based on a review of the literature and experience of SDG interaction analysis for decision making; (b) evaluate the requirements of decision makers based on an online survey of representatives of private and public organisations committed to SDG implementation at national and subnational level in Sweden; (c) assess how the approaches comply with the requirements of decision makers based on the views and opinions of developers of prominent tools. Sweden was selected due to the widely shared ambition of becoming a front runner of SDG implementation, and also considering the research team's familiarity with the local context. The focus on local and national organisations is justified by the recognition that, while the 2030 Agenda is global in nature, its implementation is expected to take place primarily at local, regional and national level.

The results of the study highlight the existence of both methodological and conceptual challenges that are relevant to the empirical analysis of SDG interactions. To effectively contribute to decision making, approaches and tools need to be easy to apply, transparent in their logic, assumptions and limitations, but also flexible and adaptable to different empirical cases, while the knowledge generated should be directly actionable and easy to interpret by decision makers. Based on the opinions of the developers, 
the tools evaluated perform very differently against the requirements of decision makers. Most tool are easy to use and to adapt to the analysis of new cases, while the results are directly understandable by decision makers. This applies also to less important requirements, such as the provision of knowledge sufficiently complete, accurate and precise. At the same time, most tools appear unable to provide results directly actionable to develop initiatives. The only criterion against which all tools perform relatively well is that of transparency.

In the next steps of the research, we plant to assess the views of decision makers on the selected tools by conducting a focus group exercise with a representative sample of decision makers. Improved understanding of the limitations and potentials of existing approaches for studying SDG interactions is considered vital to advance their analytical validity and use in decision making and, ultimately, the usefulness of the 2030 Agenda as a means of national and global governance.

\section{Introduction}

In 2015 the UN 2030 Agenda was adopted as the world's most comprehensive plan for planetary health and human development. The Agenda identifies development priorities at the local, regional, national and transnational level establishing 17 Sustainable Development Goals (SDG) and 169 targets in all policy areas (Koehler, 2016). It promises deep transformation of society including the end of hunger and poverty, while protecting the environment by limiting climate change and preserving marine and terrestrial biodiversity. A key aspect of the UN SDGs is 'achieving sustainable development in its three dimensions - economic, social and environmental, in a balanced and integrated manner' (Desa, 2016). Due to the interconnectedness of the SDGs, the potential to meet a specific goal is influenced by efforts to achieve other goals. It is likely that implementing the Agenda will bring about synergies-i.e., situations in which achievements on one goal contribute towards progress on other goals-as well as trade-offs-i.e., situations in which progress achieved on one goal will produce effects detrimental to other goals (or parts thereof). Examples of interlinkages include the possible trade-off between the increasing use of bioenergy crops to deliver climate targets at the potential expense of agricultural output for human consumption (Humpenöder et al., 2018). Others have looked at the energy needs of poverty alleviation (Mastrucci et al., 2019), the synergy between the move away from inefficient biomass cookstoves that serves both climate and health goals (Rosenthal et al., 2018), or how decarbonisation of the energy systems effects air quality (Portugal-Pereira et al., 2018). These examples are conceptually, if not quantitatively, fairly clear. There are, however, many more interactions (known and unknown) that are poorly, if at all, characterised.

Formulated as 'indivisible' within the 2030 Agenda, the SDGs are, in essence, a set of integrated objectives, the substance of which interact across a number of dimensions. This will necessitate a move beyond the siloed mental models in policy, academia, civil and wider society. A deep understanding of the interactions among SDGs is therefore a vital prerequisite in mobilising political action (Nugent, Bertram, et al., 2018). A wide range of methods, models and tools have been developed in response to the need to better understand SDG interactions. Recent reviews of the scientific literature (Bennich et al., 2020, Breuer et al., 2019) suggest that despite the common basic objective, approaches fir understanding SDG interactions differ considerably with regard to the methodological stance, the level at which the analysis is performed and the potential implications for policy action. 
The aim of this study was to conduct a critical review of the approaches available for understanding SDG interactions to support decision makers with the implementation of the 2030 Agenda. Differently from other review studies, we evaluated existing approaches directly engaging developers of approaches and tools (i.e. knowledge producers) and decision makers working on the implementation of the Agenda within private and public organisations (i.e. knowledge users). Our overall ambition was to provide a broad understanding of the support provided by existing methodologies to decision makers in light of the challenges emerging from the interconnected nature of the SDGs. To achieve the aim of the study, we elected three specific objectives:

a) identify and categorise the most prominent approaches available for understanding SDG interactions based on a review of the literature and experience of SDG interaction analysis for decision making;

b) evaluate the requirements of decision makers based on an online survey of representatives of private and public organisations committed to SDG implementation at national and subnational level in Sweden;

c) assess how the approaches selected comply with the requirements of decision makers based on the views and opinions of developers of prominent tools.

We selected Sweden as case study due to the ambitions of different organisations, including the national government, for the country to become a front runner of SDG implementation, and also considering the research team's familiarity with the local context, which facilitated data collection. Our focus on local and national organisations is justified by the recognition that, while the 2030 Agenda is global in nature, its implementation is expected to take place primarily at local, regional and national level.

In the remainder of the paper, we illustrate the methods and material employed in the study (Section 2) and the results obtained in the analysis (Section 3). In Section 4, we discuss the findings, present some concluding remarks and illustrate the next steps of the research project.

\section{Methods and materials}

\subsection{Review of the literature of approaches to understand SDG interactions}

The first objective of this study was to identify and categorise the most prominent approaches available in the literature for understanding SDG interactions. We conducted a literature search to capture articles containing words related to the SDGs and their interactions. The following Boolean search query was employed:

(("sustainable development goals") AND (SDG*) AND (link* OR relation* OR interdependence* OR connection* OR interconnection* OR integrat* OR co-benefit* OR interaction* OR linkage* OR synerg* OR trade-offs OR "trade off" OR "trade offs"))

The search covered Scopus, Web of Science and Google Scholar and was limited to English language articles from 2012 to June 2019. Rationale for the ("sustainable development goals") AND (SDG*) stipulation is that, owing to the SDGs broadness and relative novelty, many articles were returned that make only a passing reference to the "sustainable development goals". To account for non-relevant 
literature, the Boolean "AND SDG*" ensured that the "sustainable development goals" were mentioned at least twice in any article returned.

A visualisation tool to aid evidence reviews, VOSviewer (van Eck \& Waltman, 2010), was used to construct a citation network of the literature. The tool represents two metrics graphically; the total number of citations a paper received (size of circle/node), and the distribution of those citations among the literature base (connecting edges). This has several benefits, primarily the ease at which prominent papers can be located, and the identification of the core network of linked papers while allowing non-relevant literature to be discarded. For this tool to be of use, an assumption is made that papers with more citations and better connections are generally more relevant, and therefore should be the focus of further analysis. A drawback of this is the inherent visual bias shown to older papers at the expense of newer papers. This is mitigated by differentiating papers by their year of publication and then assessing papers from 2018 onwards for their potential relevance.

The literature sampling for the present review was conducted with a cut-off date in June 2019. Since then a number of studies have been published that may contribute to the literature on how the interactions are identified and analysed. In spite of this, we do not expect the inclusion of literature published in the past 12 months to change radically the list of most relevant approaches identified in Section 3.1.

\subsection{Survey of the knowledge requirements of decision makers}

The second objective of the study was to evaluate the knowledge requirements of decision makers responsible for the implementation of the Agenda in Sweden. The evaluation was conducted by conducting an online survey of decision makers' opinions.

The population of the survey consisted of 400 organisations, including businesses (large and mediumsmall), civil society organisations (such as religious groups and NGOs), national government and public agencies, as well as city and regional governments in Sweden. Organisations were selected for their formal commitment to the implementation of the Agenda as indicated by their membership of a national or international network related to the UN Agenda including, e.g., the GD - forum (GD-Forum, 2020), Glokala Sweden (UN, 2019), CONCORD (CONCORD, 2020), UN Global Compact (UN, 2020), Swedish Investors for Sustainable Development (SISD, 2019), and the Swedish Association of Local Authorities and Regions (SKR, 2019a, SKR, 2019b). Within each organisation we engaged the person(s) acting as reference point for issues related to the Agenda.

The survey was composed of two sections. The first focused on demographic information, including information about the type of organisation, the role of the respondent within the organisation and his/her experience with the 2030 Agenda, the SDGs covered in the work as well as the age class and gender group. The second part of the survey collected respondents' views regarding the relative importance of SDG knowledge requirements for supporting decision making.

We developed a list of requirements applying a qualitative framework for assessing the utility of a given approach to study SDG interactions for decision making. The framework was informed by the work of Allen et al. (2016), who reviewed modelling approaches in support of national SDG planning, and more generally by the UK's National Audit Office 'Framework to review models' (NAO, 2016). The 
application of the framework resulted in a set of eight utility criteria, i.e. requirements, referring to either the type of method applied, or the type of knowledge produced (Table 1).

Table 1. Utility criteria employed in this study to evaluate the requirements of decision makers

\begin{tabular}{l|l} 
Criteria & Description \\
\hline Easy to use tool & Considering the time, cost and effort requirements for its application \\
\hline Transparent tool & $\begin{array}{l}\text { Logic, assumptions, uncertainties and limitations are clearly described } \\
\text { and easily available to users }\end{array}$ \\
\hline Flexible and adaptable tool & With reference to its application to different case studies \\
\hline Understandable knowledge & Referring to results that can be interpreted without specialist knowledge \\
\hline Relevant knowledge & Referring only to whether the results are quantified in bio-physical units \\
\hline Actionable knowledge & $\begin{array}{l}\text { Results directly applicable to support and inform evidence-based } \\
\text { decisions }\end{array}$ \\
\hline Complete knowledge & Results that cover all scales (global, national, local) and SDGs \\
\hline Accurate knowledge & With reference to the accuracy and precision of results
\end{tabular}

In the implementation of the survey, respondents received an email containing an explanatory cover letter and an invitation to complete the survey, which was followed, after one week, by a reminder to encourage participation. After a set of demographic questions, the survey asked participants to select the most important criteria using a pair-wise comparison method referred to as best-worst, or maximum difference scaling (Max-Diff) (Louviere and Woodworth, 1991). Max-Diff is a mathematical theory about how people make choices. In comparison to other rating scales that are often used to measure importance of reasons for a decision, Max-Diff forces respondents to make choices among options while still delivering rankings that show the relative importance of the reasons being rated. The method leverages the ability to identify the best and worst from a list and, thus, simplifies the respondents' task. Traditionally, in Max-Diff analyses the survey results are analysed applying Hierarchical Bayes (HB) analysis to calculate individual preference utilities (Orme, 2009). However, it is possible to substitute the application of HB with a simple count of the preferences of each respondent by designing the survey so that (i) each item appears with each other item exactly an equal number of times and (ii) all possible combinations of items are covered. In this study, we applied this approach to design a survey containing all potential combinations of two items at the time for the eight items, resulting in 28 combinations.

\subsection{Assessment of the approaches to understand SDG interactions}

The third objective of the study was to assess how existing approaches for understanding SDG interactions perform compared to the requirements of decision makers. In order to conduct the analysis, we first identified a set of practical tools, models and methods (henceforth referred to as "tools") which represent the range of approaches identified in the review exercise (section 3.1). Then we evaluated the performance of each tool against the utility criteria selected in section 3.2 by directly engaging with experts. For each tool we involved a reference group of experts (henceforth referred to as "developers") with deep knowledge of the tool either because part of the group developing the tool or because working closely with such group. To collect the opinions of tool developers we 
conducted (10) semi-structure interviews in which interviewees were asked to illustrate the performance of their tool against each utility criterion, providing as much practical information and examples as possible.

\section{Results}

\subsection{The literature of SDG interaction methods}

This section provides an overview of the current state of scholarly research on approaches for studying and mapping interactions between SDGs. Following the removal of duplicates, a number of articles ( $\mathrm{n}$ $=798$ ) linked by at least one citation were included in the citation network of the literature constructed with the VOSviewer (van Eck \& Waltman, 2010) (Fig. 1).

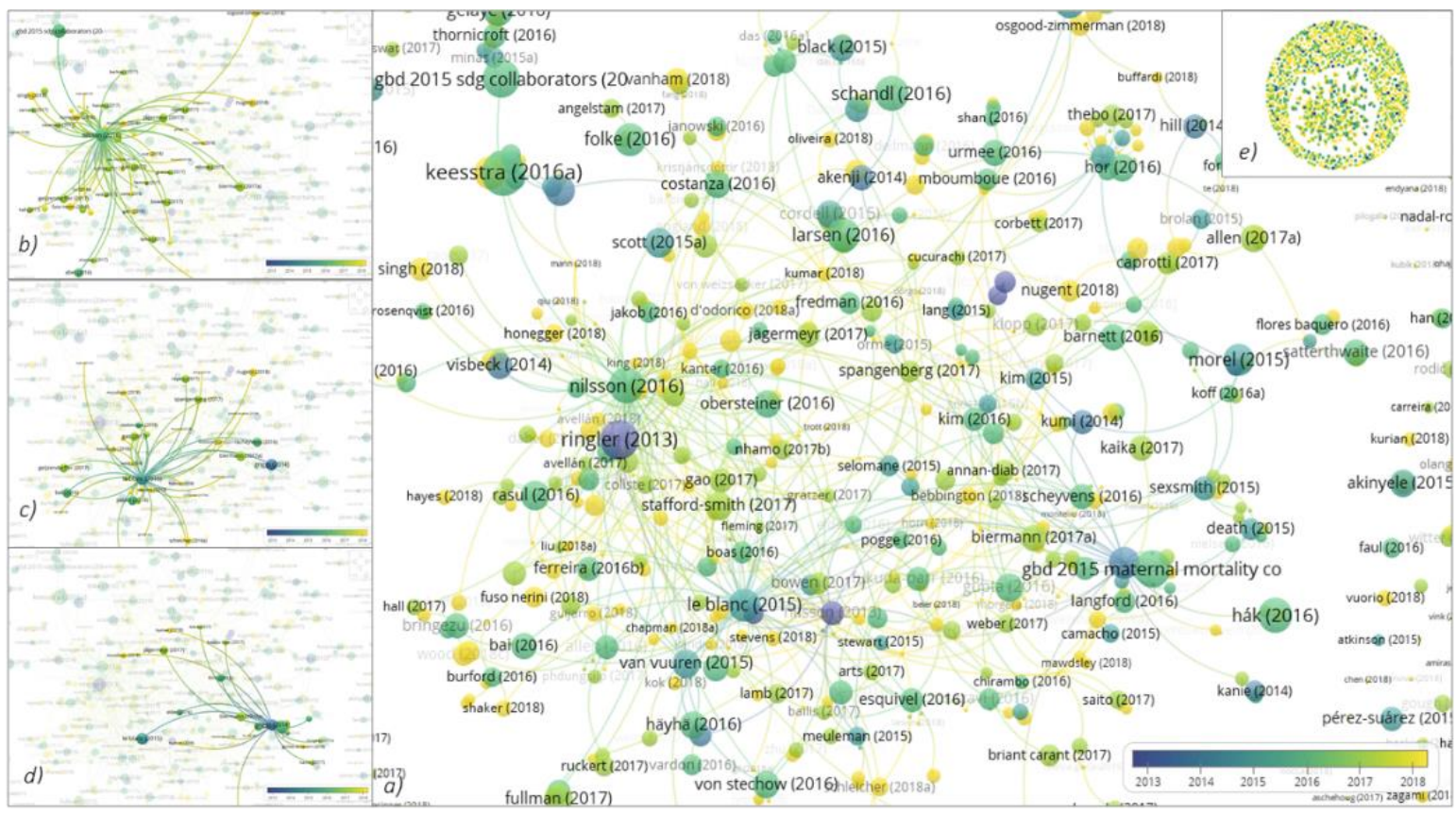

Figure 1: Citation network of SDG interaction literature

Notes: each edge (line) is a citation and each node (circle) represents a paper. Node size indicates total number of citations and colour indicates publication year. Note, total citations include those from outside the returned literature network. a) the central network area of 798 papers, b) - d) are the individual networks of three prominent papers Nilsson et al. (2016), Le Blanc (2015), Griggs et al. (2014)), e) the network in its entirety with a clear inner and outer 'ring'. Analysis performed in VOSviewer.

Based on the citation network, we were able to identify the most prominent studies, by way of citation, published on the subject (Table 2). We then matched each publication with a specific type of approach. One challenge we had to address was how to categorise approaches for understanding SDG interactions. In the SDG interaction literature, approaches have been categorised in various ways by scholars (Breuer et al., 2019, Bennich et al., 2020, Allen et al., 2016, Miola et al., 2019). In particular, Bennich et al. (2020) refer to five types of categorisation considering the policy challenges addressed, the type of interactions considered, the data sources utilised, the interaction qualifiers employed, and the method applied for the analysis. In this study, inspired by Miola et al. (2019), we applied a distinction based on the analytical methods employed to understand interactions resulting in four main categories including Linguistic approach, Expert judgement approach, Literature based 
approach, Quantitative approach and Modelling approach. It is important to note that approaches are often applied in combination. For instance, Literature based and Expert judgment approaches are often integrated with Quantitative approaches. The approaches selected for our study are discussed in greater detail in Section 3.3.

\subsection{Knowledge requirements of decision makers}

In this section, we present the results of the on-line survey of decision makers' opinions. The survey received a total of 98 complete responses. The majority of the respondents belonged to the group of Regional and local governments (35 instances), followed closely by the group of National government and public agencies (30 instances), and Business (22), with Civil society organisations at a fair distance (11) (Fig.2). Concerning the role of respondents within their organisation, the large majority was in charge of the decision-making process within the organisation (38\%) or responsible for providing knowledge about SDGs to decision makers within the organisation (52\%). Finally, the gender balance of respondents was $77 \%$ female and $33 \%$ male, while the dominant age group was $40-49$ years old.

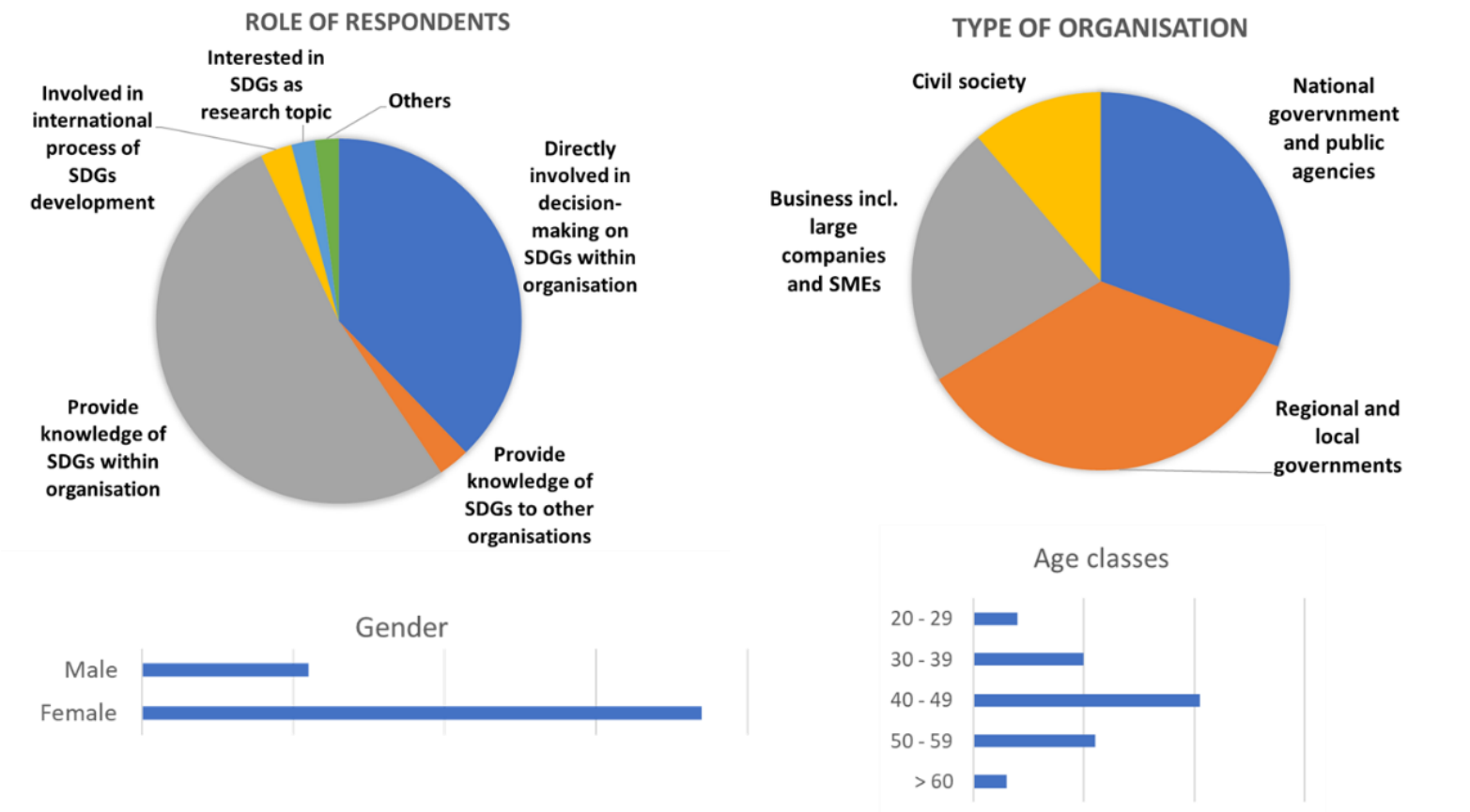

Figure 2. Respondents demographic

The survey provided also the preferences of respondents regarding the utility criteria as overall mean response to the Max-Diff survey component (Fig. 3). The results show that the ease of use of the tool, considering time, cost and efforts required, was the most important criterion with $17 \%$ of the preferences. That was followed closely by two key features of the type of information provided, which should be understandable without specialist knowledge (16.7\%) and directly applicable to support and inform evidence-based decisions, i.e. actionable (16.1\%). The fourth requirement in order of importance concerned the flexibility and adaptability of the tool to the analysis of different cases (14.2\%). These four issues were rated as top priorities by all categories of decision makers (Fig. 4). Conversely, the accuracy, relevance and completeness of the information provided consistently showed lower levels of preference among all the categories of respondents (Fig. 4). 


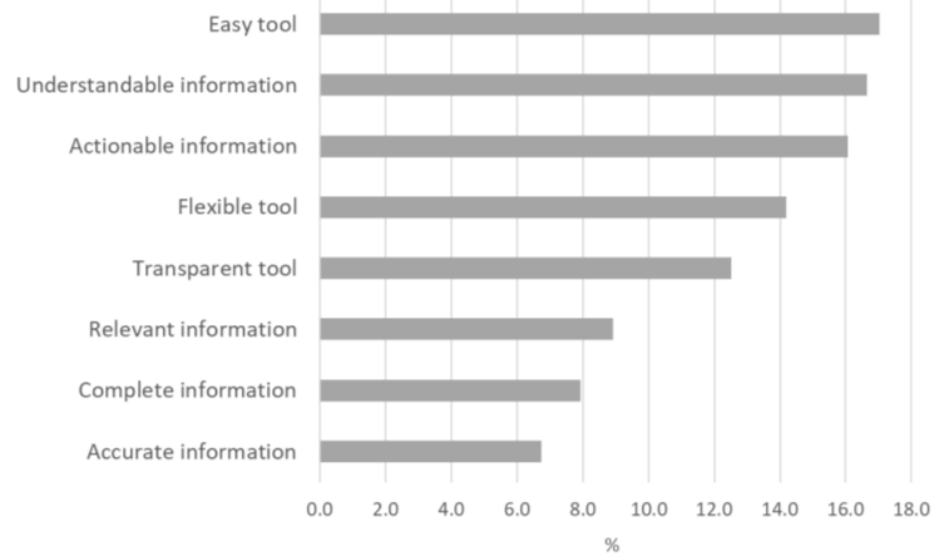

Figure 3. Importance of utility criteria based on total survey answers

Notes: Values represent the share of responses in which the criterion was selected as the most important in the pair-wise comparison. Labels indicate the resulting order of criteria

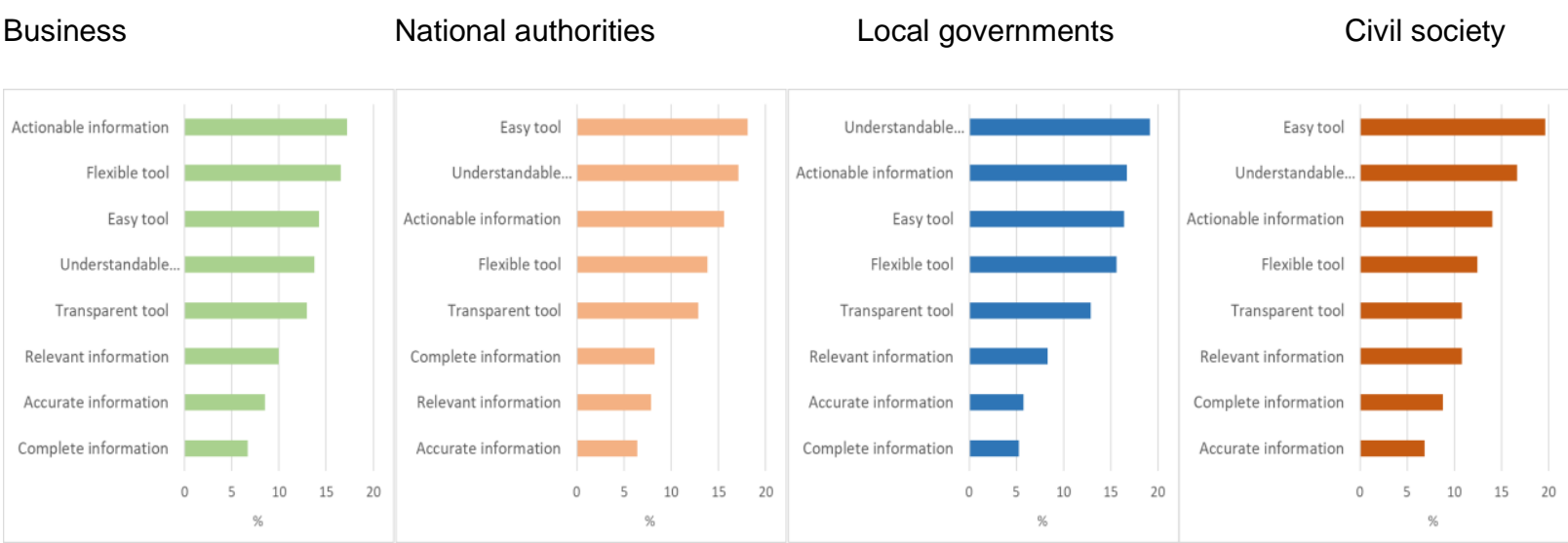

Figure 4. Importance of utility criteria for each category of organisation

Notes: Values represent the share of responses in which the criterion was selected as the most important in the pair-wise comparison. Labels indicate the resulting order of criteria

\subsection{Assessment of tools for understanding SDGs interactions}

In this section, we present the results of our assessment of approaches for studying SDG interactions. The sample selected for the assessment includes the four approaches identified in our literature review (see Section 3.1) - Expert judgement approach, Literature approach, Quantitative approach and Modelling approach. While the Linguistic approach was discarded due its limited relevance for decision making, one additional approach - Self-assessment, was added to the list based on our direct 
observations ${ }^{1}$. For the analysis, each approach was matched with one or more practical tools which rely primarily on the approach. Finally, we decided to split the category of Modelling approach into two sub-groups to reflect the significant differences existing within this category. Table 2 illustrates the approaches and tools included in the analysis providing reference to key publications.

Table 2. Approaches and tools included in the analysis.

\begin{tabular}{|c|c|c|}
\hline Approach & Tool & Key publications and references \\
\hline Expert judgment & $\begin{array}{l}\text { SDG Synergies (Stockholm } \\
\text { Environmental Institute) }\end{array}$ & $\begin{array}{l}\text { Weitz et al. (2018), (Nilsson et al., } \\
\text { 2016) }\end{array}$ \\
\hline Literature based & $\begin{array}{l}\text { SDG Interlinkages Analysis and } \\
\text { Visualization Tool (Institute for } \\
\text { Global Environmental Strategies) }\end{array}$ & Xin and Moinuddin (2017) \\
\hline $\begin{array}{l}\text { Quantitative } \\
\text { techniques }\end{array}$ & $\begin{array}{l}\text { Statistical methods (Potsdam } \\
\text { Institute) }\end{array}$ & Pradhan et al. (2017) \\
\hline $\begin{array}{l}\text { Modelling (System } \\
\text { Dynamics models) }\end{array}$ & iSDG model (Millennium Institute) & $\begin{array}{l}\text { Collste et al. (2017), (Allen et al., } \\
\text { 2019, Pedercini et al., 2019) }\end{array}$ \\
\hline $\begin{array}{l}\text { Modelling (Integrated } \\
\text { Assessment Models) }\end{array}$ & IMAGE model (Utrecht University) & $\begin{array}{l}\text { van Soest et al. (2019), (van Vuuren } \\
\text { et al., 2015) }\end{array}$ \\
\hline Self-assessment & $\begin{array}{l}\text { SDG Impact Assessment Tool } \\
\text { (Gothenburg Centre for Sustainable } \\
\text { Development) }\end{array}$ & GMV (2020) \\
\hline
\end{tabular}

Expert judgment approach and the SDG Synergies tool (SEI, 2020) - The aim of the expert judgment approach is to generate consensus on a question within a discipline or subject area where there exists uncertainty. Nilsson et al. (2016) present a conceptual framework to understand the interactions between the 17 goals by way of a qualitative seven-point typology. Interactions are informed by expert judgement, ranging from +3 for 'indivisible' goals to -3 for those believed to be 'cancelling'. The approach is prominent among SDG interaction literature, employed in multiple studies to date. The SDG Synergies tool developed by the Stockholm Environmental Institute (SEI) applies the typology for scoring interactions developed by Nilsson et al 2016 in a cross-impact matrix based on the results of an expert judgment exercise (SEI, 2020). The structure and characteristics of the SDG interlinkages network as emerging from the matrix analysis are then analysed using network analysis techniques (Weitz et al., 2018).

Literature based approach and the SDG Interlinkages Analysis and Visualization Tool (IGES, 2020) Literature reviews and document analyses have been employed to identify and analyse SDG interactions in some cases as a sole method (Manandhar et al., 2018), but more frequently in combination with other methods (Bastos Lima et al., 2017, Glover et al., 2016, Weitz et al., 2018, Xin and Moinuddin, 2017). The SDG Interlinkages Tool, developed by the Institute for Global Environmental Strategies (IGES) in 2017, relies on extensive literature reviews to identify interlinkages between the SDG targets (IGES, 2020). Literature results are often integrated with inputs from multistakeholder consultations and expert opinions before interactions are quantified based on the Global SDG indicators and other proxy indicators using relevant statistical methods. Finally, network analysis techniques and a dedicated online tool are used to visualise the structure and the characteristics of

\footnotetext{
${ }^{1}$ Although we found no scientific literature about this approach, we observed a large interest of decision makers in Sweden. Tools applying this approach are Climate Action Impact Tool developed by UNDP (2020) and SDG Impact Assessment Tool provided by the Gothenburg Centre for Sustainable Development (GMV, 2020).
} 
the SDG interlinkages network (Xin and Moinuddin, 2017). The tool has been used to conduct detailed country level studies in countries such as Ethiopia, Tanzania, Bangladesh, Indonesia, Vietnam and Laos.

Quantitative approach and statistical methods - Statistical analysis is a broad area, forming part of many methods across multiple domains. The SDG literature is no different, with techniques from ranked correlation to more involved factor and causality analyses. Techniques in general look to statistically quantify correlation between two or more variables (Pradhan et al., 2017), or to reduce complexity by constructing composite indices of the SDGs (Shaker, 2018). However, data availability, the assumption of linearity in many techniques and the presence of confounding variables when performing bivariate analysis are known limitations of this type of analyses (Spaiser et al., 2017, Pradhan et al., 2017). Pradhan et al. (2017) employed data from UNSD (2016) on 122 indicators for a total of 227 countries between the years 1983 and 2016 to conduct a correlation analysis between unique pairs of SDG indicator time-series. In this way, the authors were able to capture the existence of significant synergies and trade-offs within one particular goal and between different goals at national and global level.

Modelling approach with System Dynamics and iSDG model (MI, 2020) - iSDG is a System Dynamics (SD) model developed by the Millennium Institute to map causal feedbacks between SDG goals and targets employing stock and flow, and causal loop diagrams (MI, 2020). In general, SD models are simplified representations of real-world systems developed to facilitate learning about the hypothesized causal structure and behaviour of real-world systems (Collste et al., 2017). Similarly, iSDG seeks to provide a credible representation of real-world development that can be used to simulate specific policies over the SDG time horizon and assess synergies/trade-offs associated with policy mixes. The general structure of the iSDG model looks at 30 sectors with a series of possible policy interventions. Validation is performed against historical data and a forecast is generated out to 2030 (MI, 2016). The iSDG model has been widely used at national level including recent case studies of Tanzania, Australia, Côte d'Ivoire, Malawi and Senegal (Allen et al., 2019, Collste et al., 2017, Pedercini et al., 2019).

Modelling approach with Integrated Assessment Models (IAM) and IMAGE model (PBL, 2020) - IAMs offer an integrated perspective on complex human-environment interactions and can, thus, contribute to an assessment of the strategies to achieve multiple SDGs simultaneously (van Soest et al., 2019, Riahi et al., 2017). These models provide a global picture, highlighting the differences between regions and including displacement effects. An example of IAMs is IMAGE (Integrated Model to Assess the Global Environment), an ecological-environmental model framework able to simulate long term environmental consequences of human activities worldwide (PBL, 2020). Originally developed representing interactions between society, the biosphere and the climate system (Bouwman et al., 2006), the model has since been further developed with expanded sets of interactions across sectors and systems to analyse the connections between various SDG related objectives (van Vuuren et al., 2015).

Self-assessment approach and SDG Impact Assessment Tool (GMV, 2020) - Self-assessment is essentially a process of reflection on the impacts that solutions, organizations, projects and other initiatives might have on the SDGs. The SDG Impact Assessment Tool developed by the Gothenburg Centre for Sustainable Development aims to stimulate a better understanding of the complexity of sustainable development and the different aspects of the SDGs (GMV, 2020). The tool is intended firstand-foremost as a learning experience and as a first strategic step towards improving sustainability. 
The tool helps users to identify knowledge gaps and provides a better understanding of how solutions relate to the Agenda in its complexity, thereby making users better equipped to prioritize forward actions.

In this study, we evaluated each tool by engaging directly tool developers. The results of the (10) interviews conducted with developers, presented in Table 3 (further details are available in Table a of Appendix) show how each tool performs against the eight utility criteria presented in Section 2.2. The results of each tool are based solely on the opinions expressed by the developers of each tool during the interviews. The results provide qualitative insights on the performance of each tool, which can be used to derive more general insights on the performance of the approaches underlying the tools.

The overall results show that the six tools perform very differently on a number of criteria. For instance, regarding criterion 1 - ease of use of the tool, the most important criterion for decision makers, the sample of tools covers the entire range of potential alternatives from "no" to "high" compliance with the requirement. Although most developers suggest that their tool is easy to use, the level of investment required ranges from 2 hours at no additional costs for SDG IAT (Self-assessment approach) to several years and a multi-million euros bill for IMAGE (Modelling approach with IAM). A similar pattern can be observed also with regard to criterion n. 2 (Information is understandable) and n. 4 (Tool is flexible and adaptable). For the former, the range of alternatives go from tools that do not require specialist knowledge (several tools) to those requiring specialist knowledge with direct experience with the tool (IMAGE model). For the latter criterion, it emerged that several tools can be applied to new cases without any modification, while others require several years of work and a multimillion euros investment (IMAGE model).

The only criterion against which all tools perform relatively well, based on the opinions of developers, is that of transparency (n. 5). However, transparency did not emerge as a top priority for participants of our decision maker survey. Moreover, transparency is interpreted by developers as a critical feature of tools with reference to other developers and experts and not meaning transparent for decision makers.

Among the criteria against which most tools perform poorly we identify actionability (criterion 3) and relevance (criterion 6) of the results. In particular, while actionability, or the provision of results which can be directly used to adopt evidence-based decisions, emerged in our survey among the most important features for all categories of decision makers, most developers claim that the results of their tools are not directly actionable. A notable exception is iSDG (Modelling approach with SD). Regarding the relevance of results, interpreted as results provided in bio-physical units, was largely considered of minor importance by decision makers in the survey.

Finally, the performance of most tools on criteria n. 7 (Completeness of information) and n. 8 (Accuracy and precision of information) is largely positive with most tools capable, or potentially capable, to provide knowledge of SDG interactions sufficiently complete and accurate/precise. Worth noting that developers, in line with the largely shared interpretation of the Agenda as indivisible, consider knowledge completeness important and thus seek to cover multiple SDGs and geographical scales (criterion n. 7), while knowledge users do not see completeness as a critical feature. 
Table 3. Performance of selected tools based on opinions of tool developers

Notes: - largely no compliance, +/- partial compliance, + compliance, ++ high compliance, * potentially complying; ** formal compliance.

\begin{tabular}{|c|c|c|c|c|c|c|}
\hline Utility criteria & $\begin{array}{l}\text { Experts (SDG } \\
\text { Synergies) }\end{array}$ & \begin{tabular}{|} 
Literature \\
(SDG IAVT)
\end{tabular} & $\begin{array}{c}\text { Statistical } \\
\text { techniques }\end{array}$ & $\begin{array}{l}\text { Modelling } \\
\text { (iSDG) }\end{array}$ & $\begin{array}{l}\text { Modelling } \\
\text { (IMAGE) }\end{array}$ & $\begin{array}{l}\text { Self-assessment } \\
\text { (SDG IAT) }\end{array}$ \\
\hline 1. Tool is easy to use & $+*$ & + & + & $+/-$ & - & ++ \\
\hline $\begin{array}{l}\text { 2. Information is } \\
\text { understandable }\end{array}$ & $+/-$ & + & $+/-$ & + & - & ++ \\
\hline 3. Information is actionable & - & - & - & + & - & - \\
\hline $\begin{array}{l}\text { 4. Tool is flexible and } \\
\text { adaptable to the } \\
\text { characteristics of each case }\end{array}$ & ++ & + & $+*$ & $+/-$ & - & ++ \\
\hline 5. Tool is transparent & ++ & + & $+/-$ & ++ & $+/-* *$ & ++ \\
\hline $\begin{array}{l}\text { 6. Information is relevant } \\
\text { (bio-physical units) }\end{array}$ & - & - & - & + & ++ & - \\
\hline $\begin{array}{l}\text { 7. Information is complete } \\
\text { (scales and SDGs) }\end{array}$ & $+/-$ & $+*$ & $+*$ & $+^{*}$ & - & + \\
\hline $\begin{array}{l}\text { 8. Information is accurate } \& \\
\text { precise }\end{array}$ & - & + & ++ & $+/-$ & $+/-$ & - \\
\hline
\end{tabular}

\section{Discussion and final remarks}

The aim of this study was to conduct a critical review of the approaches available for understanding SDG interactions with the ambition to provide a broad and critical understanding of existing approaches in light of the support required by decision makers. The preliminary results illustrated in this paper show that there is a plethora of approaches that have been specifically developed in recent years for the analysis of SDG interactions, or adapted for this task. Some approaches have received more attention in the literature and practice of SDG interaction analysis. Our review of the literature helped us to identify the most prominent studies, by way of citation, published on the subject. From this sample of studies, we developed a categorisation of most relevant approaches applied to analyse SDG interactions. These approaches include Self-assessment, Expert judgement, Literature based, Quantitative techniques and Modelling with SD and Modelling with IAM. However, further approaches were identified (see Table a, appendix) which could become popular in the future.

A critical piece of evidence provided in this study is about the requirements of decision makers. Our analysis showed that decision makers in Sweden consider more important the ease of use, transparency and flexibility of tools as well as the actionability and interpretability of the results, while the completeness, accuracy and relevance of the results are constantly rated as less important. These results are partially in conflict with our initial expectation, that tools and approaches have different features that fit different types of decisions considering scale and scope. However, the results of the survey of decision makers showed that the importance allocated to different utility criteria does not vary significantly across different categories of decision makers. This is rather puzzling and justifies a deeper investigation of the views of knowledge users in the next steps of the research project. 
Our evaluation of the tools and approaches available in the literature for understanding SDG interactions showed that these perform very differently against the utility criteria employed in the study to evaluate decision makers requirements. However, since our assessment was based only on the opinions of tool developers, we consider it to be only one side of the medal. In the next steps of the research, we plan to assess the performance of tools and approaches based on the views of decision makers. To that end, we will conduct one focus group engaging representatives of all categories of decision makers included in the survey. Participants will be asked to evaluate the performance of each tool/approach identifying minimum acceptable levels of performance.

The outputs of these activities will contribute to the SDG interaction literature and will provide insights for the development of tools better suited to support decision making. Understanding of the limitations and potentials of current tools and approaches for studying SDG interactions is crucial in order to improve their analytical validity and use in decision making contributing to the usefulness of the 2030 Agenda as a means of national and global governance. 


\section{List of references}

ALLEN, C., METTERNICHT, G. \& WIEDMANN, T. 2016. National pathways to the Sustainable Development Goals (SDGs): A comparative review of scenario modelling tools. Environmental Science \& Policy, 66, 199-207.

ALLEN, C., METTERNICHT, G., WIEDMANN, T. \& PEDERCINI, M. 2019. Greater gains for Australia by tackling all SDGs but the last steps will be the most challenging. Nature Sustainability, 2, 1041-1050.

BASTOS LIMA, M. G., KISSINGER, G., VISSEREN-HAMAKERS, I. J., BRAÑA-VARELA, J. \& GUPTA, A. 2017. The Sustainable Development Goals and REDD+: assessing institutional interactions and the pursuit of synergies. International Environmental Agreements: Politics, Law and Economics, 17, 589-606.

BENNICH, T., WEITZ, N. \& CARLSEN, H. 2020. Deciphering the scientific literature on SDG interactions: A review and reading guide. Science of The Total Environment, 138405.

BOUWMAN, A. F., KRAM, T. \& KLEIN GOLDEWIJK, K. 2006. Integrated modelling of global environmental change: An overview of IMAGE 2.4.

BREUER, A., JANETSCHEK, H. \& MALERBA, D. 2019. Translating sustainable development goal (SDG) interdependencies into policy advice. Sustainability, 11, 2092.

COLLSTE, D., PEDERCINI, M. \& CORNELL, S. E. 2017. Policy coherence to achieve the SDGs: using integrated simulation models to assess effective policies. Sustainability science, 12, 921-931.

CONCORD. 2020. CONCORD Sweden [Online]. Available: https://concord.se/eng-about-us [Accessed January 2020].

DESA, U. 2016. Transforming our world: The 2030 agenda for sustainable development.

GD-FORUM. 2020. Government agencies and the 2030 Agenda [Online]. Available: https://www.folkhalsomyndigheten.se/gd-forum-agenda-2030/english/ [Accessed].

GLOVER, D., HERNANDEZ, K. \& RHYDDERCH, A. 2016. A foresight scenario method for thinking about complex sustainable development interactions.

GMV. 2020. SDG Impact Assessment Tool [Online]. Available: https://www.unsdsn-ne.org/ouractions/initiatives/sdg-impact-tool/ [Accessed 15 Janurary 2020].

GRIGGS, D., STAFFORD SMITH, M., ROCKSTRÖM, J., ÖHMAN, M. C., GAFFNEY, O., GLASER, G., KANIE, N., NOBLE, I., STEFFEN, W. \& SHYAMSUNDAR, P. 2014. An integrated framework for sustainable development goals. Ecology and Society, 19.

HUMPENÖDER, F., POPP, A., BODIRSKY, B. L., WEINDL, I., BIEWALD, A., LOTZE-CAMPEN, H., DIETRICH, J. P., KLEIN, D., KREIDENWEIS, U. \& MÜLLER, C. 2018. Large-scale bioenergy production: how to resolve sustainability trade-offs? Environmental Research Letters, 13, 024011.

IGES. 2020. SDG Interlinkages Analysis \& Visualisation Tool (V3.0) [Online]. Available: https://sdginterlinkages.iges.jp/visualisationtool.html [Accessed 20 March 2020].

KOEHLER, G. 2016. Assessing the SDGs from the standpoint of eco-social policy: Using the SDGs subversively. Journal of International and Comparative Social Policy, 32, 149-164.

LE BLANC, D. 2015. Towards integration at last? The sustainable development goals as a network of targets. Sustainable Development, 23, 176-187.

LOUVIERE, J. J. \& WOODWORTH, G. G. 1991. Best-worst scaling: A model for the largest difference judgments. University of Alberta: Working Paper.

MANANDHAR, M., HAWKES, S., BUSE, K., NOSRATI, E. \& MAGAR, V. 2018. Gender, health and the 2030 agenda for sustainable development. Bull World Health Organ, 96, 643-52.

MASTRUCCI, A., BYERS, E., PACHAURI, S. \& RAO, N. D. 2019. Improving the SDG energy poverty targets: Residential cooling needs in the Global South. Energy and Buildings, 186, 405-415.

MI. 2016. iSDG - Model Documentation [Online]. Available: http://www.isdgs.org/documentation [Accessed 25 February 2020].

MI. 2020. iSDG - Integrated Simulation Tool [Online]. Available: https://www.millenniuminstitute.org/isdg [Accessed 25 February 2020]. 
MIOLA, A., BORCHARDT, S., NEHER, F. \& BUSCAGLIA, D. 2019. Interlinkages and policy coherence for the Sustainable Development Goals implementation. JRC Technical Reports.

NILSSON, M., GRIGGS, D. \& VISBECK, M. 2016. Policy: map the interactions between Sustainable Development Goals. Nature News, 534, 320.

ORME, B. 2009. Maxdiff analysis: Simple counting, individual-level logit, and hb. Sawtooth Software. PBL. 2020. IMAGE model 3.0 [Online]. Available:

https://models.pbl.nl/image/index.php/Welcome to IMAGE 3.0 Documentation [Accessed January 2020].

PEDERCINI, M., ARQUITT, S., COLLSTE, D. \& HERREN, H. 2019. Harvesting synergy from sustainable development goal interactions. Proceedings of the National Academy of Sciences, 116, 23021-23028.

PORTUGAL-PEREIRA, J., KOBERLE, A., LUCENA, A. F., ROCHEDO, P. R., IMPÉRIO, M., CARSALADE, A. M., SCHAEFFER, R. \& RAFAJ, P. 2018. Interactions between global climate change strategies and local air pollution: lessons learnt from the expansion of the power sector in Brazil. Climatic Change, 148, 293-309.

PRADHAN, P., COSTA, L., RYBSKI, D., LUCHT, W. \& KROPP, J. P. 2017. A systematic study of Sustainable Development Goal (SDG) interactions. Earth's Future, 5, 1169-1179.

RIAHI, K., VAN VUUREN, D. P., KRIEGLER, E., EDMONDS, J., O'NEILL, B. C., FUJIMORI, S., BAUER, N., CALVIN, K., DELLINK, R., FRICKO, O., LUTZ, W., POPP, A., CUARESMA, J. C., KC, S., LEIMBACH, M., JIANG, L., KRAM, T., RAO, S., EMMERLING, J., EBI, K., HASEGAWA, T., HAVLIK, P., HUMPENÖDER, F., DA SILVA, L. A., SMITH, S., STEHFEST, E., BOSETTI, V., EOM, J., GERNAAT, D., MASUI, T., ROGEU, J., STREFLER, J., DROUET, L., KREY, V., LUDERER, G., HARMSEN, M., TAKAHASHI, K., BAUMSTARK, L., DOELMAN, J. C., KAINUMA, M., KLIMONT, Z., MARANGONI, G., LOTZE-CAMPEN, H., OBERSTEINER, M., TABEAU, A. \& TAVONI, M. 2017. The Shared Socioeconomic Pathways and their energy, land use, and greenhouse gas emissions implications: An overview. Global Environmental Change, 42, 153-168.

ROSENTHAL, J., QUINN, A., GRIESHOP, A. P., PILLARISETTI, A. \& GLASS, R. I. 2018. Clean cooking and the SDGs: Integrated analytical approaches to guide energy interventions for health and environment goals. Energy for Sustainable Development, 42, 152-159.

SEI. 2020. SDG Synergies: An approach for coherent 2030 Agenda implementation [Online]. Available: https://www.sei.org/publications/sdg-synergies-factsheet/ [Accessed 13 February 2020 ].

SHAKER, R. R. 2018. A mega-index for the Americas and its underlying sustainable development correlations. Ecological indicators, 89, 466-479.

SISD 2019. Swedish Investors for Sustainable Development and the SDGs. In: AGENCY, S. I. D. C. (ed.).

SKR 2019a. Municipal initiatives within Agenda 2030. In: REGIONS, S. A. O. L. A. A. (ed.).

SKR 2019b. Regional initiatives within Agenda 2030. In: REGIONS, S. A. O. L. A. A. (ed.).

SPAISER, V., RANGANATHAN, S., SWAIN, R. B. \& SUMPTER, D. J. 2017. The sustainable development oxymoron: quantifying and modelling the incompatibility of sustainable development goals. International Journal of Sustainable Development \& World Ecology, 24, 457-470.

UN, A. S. 2019. Glokala sverige - agenda 2030 i kommuner och regioner. Available: https://fn.se/wpcontent/uploads/2019/03/L\%C3\%A4gesrapport-Glokala-Sveriges-pilot\%C3\%A5r.pdf [Accessed January 2020].

UN, G. C. 2020. UN Global Compact - participants [Online]. Available:

https://www.unglobalcompact.org/what-is-

gc/participants/search?utf8=\%E2\%9C\%93\&search\%5Bkeywords\%5D=\&search\%5Bcountries $\% 5 \mathrm{D} \% 5 \mathrm{~B} \% 5 \mathrm{D}=190 \&$ search\%5Bper page $\% 5 \mathrm{D}=10 \&$ search\%5Bsort field\%5D=\&search\%5Bsor $\mathrm{t}$ direction\%5D=asc [Accessed February 2020].

UNDP. 2020. Climate Action Impact Tool [Online]. Available: https://climateimpact.undp.org/\#!/

[Accessed 20 April 2020].

UNSD 2016. SDG indicators global database. United Nations Statistics Division. 
VAN SOEST, H. L., VAN VUUREN, D. P., HILAIRE, J., MINX, J. C., HARMSEN, M. J., KREY, V., POPP, A., RIAHI, K. \& LUDERER, G. 2019. Analysing interactions among Sustainable Development Goals with Integrated Assessment Models. Global Transitions, 1, 210-225.

VAN VUUREN, D. P., KOK, M., LUCAS, P. L., PRINS, A. G., ALKEMADE, R., VAN DEN BERG, M., BOUWMAN, L., VAN DER ESCH, S., JEUKEN, M., KRAM, T. \& STEHFEST, E. 2015. Pathways to achieve a set of ambitious global sustainability objectives by 2050: Explorations using the IMAGE integrated assessment model. Technological Forecasting and Social Change, 98, 303323.

WEITZ, N., CARLSEN, H., NILSSON, M. \& SKÅNBERG, K. 2018. Towards systemic and contextual priority setting for implementing the 2030 Agenda. Sustainability science, 13, 531-548.

XIN, Z. \& MOINUDDIN, M. 2017. Sustainable Development Goals Interlinkages and Network Analysis: A practical tool for SDG integration and policy coherence, Institute for Global Environmental Strategies. 


\section{Appendix}

Table a: A summary of the approaches identified in literature on SDG interactions, synergies and trade-offs.

\begin{tabular}{|c|c|c|c|}
\hline Approach & Description & SDG Example & Key Example Study \\
\hline $\begin{array}{l}\text { Literature } \\
\text { review }\end{array}$ & $\begin{array}{l}\text { Interactions identified } \\
\text { and analysed through } \\
\text { document analysis. }\end{array}$ & $\begin{array}{l}\text { Qualitative model of SDGs and } \\
\text { targets connections informed } \\
\text { by literature and other means } \\
\text { of qualitative insight. }\end{array}$ & $\begin{array}{l}\text { (Xin and Moinuddin, } \\
\text { 2017) }\end{array}$ \\
\hline $\begin{array}{l}\text { Expert } \\
\text { elicitation }\end{array}$ & $\begin{array}{l}\text { Systematic judgement } \\
\text { of uncertain } \\
\text { issue/phenomena by } \\
\text { group of experts. }\end{array}$ & $\begin{array}{l}\text { Direction and strength of } \\
\text { interactions e.g. Nilsson's }+/-3 \\
\text { scale. }\end{array}$ & (Nilsson et al., 2016) \\
\hline $\begin{array}{l}\text { Network } \\
\text { analysis }\end{array}$ & $\begin{array}{l}\text { Graphical } \\
\text { representation of a } \\
\text { system and its } \\
\text { interactions with nodes } \\
\text { are the variables, edges } \\
\text { are the links. }\end{array}$ & $\begin{array}{l}\text { Analysis of SDG target wording } \\
\text { to generate a network to } \\
\text { understand connections } \\
\text { between SDGs. }\end{array}$ & (Le Blanc, 2015) \\
\hline $\begin{array}{l}\text { Causal loop } \\
\text { diagrams }\end{array}$ & $\begin{array}{l}\text { System view of the } \\
\text { interconnectedness of } \\
\text { the elements within a } \\
\text { complex issue. }\end{array}$ & $\begin{array}{l}\text { Diagram }- \text { with }+/ \text { - arrows and } \\
\text { reinforcing loop - of the } 17 \\
\text { goals and their immediate } \\
\text { impacts. }\end{array}$ & (Zhang et al., 2016) \\
\hline $\begin{array}{l}\text { Natural } \\
\text { language } \\
\text { processing } \\
\text { (NLP) }\end{array}$ & $\begin{array}{l}\text { Application of } \\
\text { computer science and } \\
\text { Al to text and speech. }\end{array}$ & $\begin{array}{l}\text { Keyword and topic modelling of } \\
\text { strategic documents on the } \\
\text { SDGs and sustainable } \\
\text { development to understand } \\
\text { consistency. }\end{array}$ & (Dörgő et al., 2018) \\
\hline $\begin{array}{l}\text { Participatory } \\
\text { modelling }\end{array}$ & $\begin{array}{l}\text { Engages stakeholders } \\
\text { to collaboratively } \\
\text { model an area of } \\
\text { interest. Can also be } \\
\text { quantitative. }\end{array}$ & $\begin{array}{l}\text { Qualitative model of SDGs and } \\
\text { targets as a complex system } \\
\text { with connections informed by } \\
\text { experts, stakeholders, } \\
\text { literature, workshops and other } \\
\text { means of qualitative insight. } \\
\text { Can use abductive logic. }\end{array}$ & (Neumann et al., 2018) \\
\hline $\begin{array}{l}\text { System } \\
\text { Dynamics } \\
\text { models }\end{array}$ & $\begin{array}{l}\text { Modelling complex } \\
\text { system over time by } \\
\text { way of stocks, flows, } \\
\text { and feedback loops. }\end{array}$ & $\begin{array}{l}\text { iSDG - a system dynamics } \\
\text { model of multiple sectors and } \\
\text { policy interventions built in } \\
\text { Vensim modelling software. }\end{array}$ & (Collste et al., 2017) \\
\hline $\begin{array}{l}\text { Integrated } \\
\text { Assessment } \\
\text { Models }\end{array}$ & $\begin{array}{l}\text { Macro-level cost } \\
\text { (usually) optimisation } \\
\text { of coupled climate, } \\
\text { economic and other } \\
\text { domain models for the } \\
\text { purpose of exploring } \\
\text { scenarios and 'what if' } \\
\text { questions. }\end{array}$ & $\begin{array}{l}\text { Development of climate change } \\
\text { mitigation scenarios consistent } \\
\text { with delivering the SDGs and } \\
\text { the synergies and trade-offs } \\
\text { within these relationships. }\end{array}$ & (Grubler et al., 2018) \\
\hline $\begin{array}{l}\text { Statistical } \\
\text { models }\end{array}$ & $\begin{array}{l}\text { Mathematical } \\
\text { representation of } \\
\text { sample data to } \\
\text { generate population }\end{array}$ & $\begin{array}{l}\text { Factor analysis (explanatory and } \\
\text { confirmatory) to reduce many } \\
\text { observed variables to a latent } \\
\text { factor that explain sufficient }\end{array}$ & (Spaiser et al., 2017) \\
\hline
\end{tabular}


insights given a set of assumptions.

Differential A set of functions of equations (DE) multiple variables that vary with respect another variable.

Goal programming

Optimisation problem for where there are multiple factors to optimise. Technique to solve multi-objective decision problems.

Spatial analysis Analysis of data behaviour, trends, phenomena that is expressed spatially.

Econometrics Mathematical and statistical methods applied to data to derive empirical economic relationships. variance in the data. I.e.

construct an SDG index factor.

DE models applied to observed (Spaiser et al., 2017) SDG data. Bayesian selection used to pick 'best' model.

Across the SDGs, minimise the (Guijarro and Poyatos, deviation between current progress and the target. 2018)

Euclidean distance to assess (dos Santos and correlation between Balestieri, 2018) socioeconomic variables and electricity use.

Welfare utility function that (Barbier and Burgess, considers SDG trade-offs.
2017) 
Table b. Performance of existing tools based on opinions of tool developers (additional details)

\begin{tabular}{|c|c|c|c|c|c|c|c|c|c|c|c|c|}
\hline \multirow[b]{2}{*}{$\begin{array}{l}\text { Utility } \\
\text { criteria }\end{array}$} & \multicolumn{2}{|c|}{$\begin{array}{c}\text { iSDG - System Dynamics } \\
\text { modelling }\end{array}$} & \multicolumn{2}{|c|}{$\begin{array}{l}\text { IMAGE - Integrated } \\
\text { Assessment Models }\end{array}$} & \multicolumn{2}{|c|}{$\begin{array}{c}\text { SDG IAT - } \\
\text { Self-reflection }\end{array}$} & \multicolumn{2}{|c|}{ Statistical techniques } & \multicolumn{2}{|c|}{$\begin{array}{l}\text { SDG Synergies - } \\
\text { Expert judgment }\end{array}$} & \multicolumn{2}{|c|}{$\begin{array}{l}\text { SDG IAVT - } \\
\text { Literature }\end{array}$} \\
\hline & $\begin{array}{l}\text { Perfor } \\
\text { mance }\end{array}$ & Comments & $\begin{array}{l}\text { Perfor } \\
\text { mance }\end{array}$ & Comments & $\begin{array}{l}\text { Perfor } \\
\text { mance }\end{array}$ & Comments & $\begin{array}{l}\text { Perfor } \\
\text { mance }\end{array}$ & Comments & $\begin{array}{l}\text { Perfor } \\
\text { mance }\end{array}$ & Comments & $\begin{array}{l}\text { Perfor } \\
\text { mance }\end{array}$ & Comments \\
\hline $\begin{array}{l}\text { 1. Tool is } \\
\text { easy to use - } \\
\text { time, cost } \\
\text { and other } \\
\text { requirement }\end{array}$ & RATHER & \begin{tabular}{|l|} 
Applications of iSDG \\
require 2-3 months, \\
one FTE expert and \\
dedicated \\
engagement \\
activities. Tool \\
provided free of \\
charge for non- \\
commercial \\
applications. Brand \\
new SD model \\
requires much longer.
\end{tabular} & NOT & $\begin{array}{l}\text { Complex task } \\
\text { usually part of } \\
\text { multi-year research } \\
\text { projects, with } \\
\text { investments in the } \\
\text { range of several } \\
\text { million Euros }\end{array}$ & VERY & $\begin{array}{l}\text { Quick application } \\
\text { which requires } \\
\text { just } 2 \mathrm{~h} \text { for a } \\
\text { worthwhile } \\
\text { exercise. No } \\
\text { additional costs } \\
\text { involved. }\end{array}$ & YES & \begin{tabular}{|l|} 
Conventional \\
statistical \\
analysis easily \\
and quickly \\
performed with \\
basic statistical \\
knowledge. \\
Data collection \\
and cleaning \\
can be \\
demanding. \\
\end{tabular} & $\begin{array}{l}\text { POTENTI } \\
\text { ALLY } \\
\text { YES }\end{array}$ & $\begin{array}{l}\text { Highly dependent on } \\
\text { the cost of engaging } \\
\text { experts: minimum } \\
2+2 \text { days required, } \\
\text { and cost of } \\
\text { contextualising the } \\
\text { analysis to the specific } \\
\text { case study. }\end{array}$ & YES & $\begin{array}{l}\text { Application requires } \\
\text { minimum } 1 \text { month } \\
\text { at national level, } \\
\text { and longer at sub- } \\
\text { national level. Tool } \\
\text { provided free of } \\
\text { charge. }\end{array}$ \\
\hline $\begin{array}{l}\text { 2. Informati } \\
\text { on is } \\
\text { understanda } \\
\text { ble - results } \\
\text { can be } \\
\text { interpreted } \\
\text { without } \\
\text { specialist } \\
\text { knowledge }\end{array}$ & YES & $\begin{array}{l}\text { Results are usually } \\
\text { easy to interpret } \\
\text { directly by decision } \\
\text { makers. However, } \\
\text { experts have a vital } \\
\text { role in development, } \\
\text { adaptation and } \\
\text { application of iSDG } \\
\text { and SD models in } \\
\text { general. }\end{array}$ & NOT & $\begin{array}{l}\text { Results } \\
\text { interpretation is not } \\
\text { a simple task. } \\
\text { Information is } \\
\text { complex and } \\
\text { difficult to interpret, } \\
\text { even for experts } \\
\text { who did not } \\
\text { participated the } \\
\text { model development } \\
\text { - this has been } \\
\text { improving in recent } \\
\text { years. } \\
\end{array}$ & VERY & $\begin{array}{l}\text { No need for } \\
\text { specialists to be } \\
\text { involved in the } \\
\text { interpretation of } \\
\text { the results. }\end{array}$ & $\begin{array}{l}\text { PARTLY } \\
\text { YES }\end{array}$ & $\begin{array}{l}\text { Results of the } \\
\text { correlation } \\
\text { analysis are easy } \\
\text { to understand, } \\
\text { but the } \\
\text { interpretation } \\
\text { of those results } \\
\text { for decision } \\
\text { making requires } \\
\text { the engagement } \\
\text { of local experts }\end{array}$ & $\begin{array}{l}\text { PARTLY } \\
\text { YES } \\
\end{array}$ & $\begin{array}{l}\text { Results of the matrix } \\
\text { analysis can be } \\
\text { interpreted directly by } \\
\text { decision makers. } \\
\text { Results of the } \\
\text { network analysis, } \\
\text { conducted as part of } \\
\text { the tool, require the } \\
\text { contribution of } \\
\text { experts }\end{array}$ & YES & $\begin{array}{l}\text { Results are } \\
\text { understandable } \\
\text { without previous } \\
\text { knowledge and/or } \\
\text { experience with the } \\
\text { tool. }\end{array}$ \\
\hline $\begin{array}{l}\text { 3. Informati } \\
\text { on is } \\
\text { actionable - } \\
\text { results }\end{array}$ & YES & \begin{tabular}{|l|} 
Results provide \\
practical and \\
contextual knowledge \\
which can be \\
employed by decision
\end{tabular} & NOT & \begin{tabular}{|l|} 
IMAGE provides \\
solid, evidence- \\
based knowledge. \\
However, it tends to \\
indicate general
\end{tabular} & NOT & $\begin{array}{l}\text { Results not } \\
\text { directly } \\
\text { actionable, except } \\
\text { concerning the } \\
\text { identification of }\end{array}$ & NOT & $\begin{array}{l}\text { The tool tells } \\
\text { what } \\
\text { worked/not } \\
\text { worked in the } \\
\text { past. This }\end{array}$ & NOT & \begin{tabular}{|l|} 
The tool provides \\
systemic \\
understanding that is \\
useful to decision \\
makers. But it does
\end{tabular} & NOT & $\begin{array}{l}\text { The knowledge } \\
\text { provided is useful to } \\
\text { support the decision } \\
\text { making process. } \\
\text { However, decisions }\end{array}$ \\
\hline
\end{tabular}




\begin{tabular}{|c|c|c|c|c|c|c|c|c|c|c|c|c|}
\hline $\begin{array}{l}\text { directly } \\
\text { support and } \\
\text { inform } \\
\text { evidence- } \\
\text { based } \\
\text { decisions }\end{array}$ & & $\begin{array}{l}\text { makers to develop } \\
\text { evidence-based } \\
\text { initiatives. }\end{array}$ & & $\begin{array}{l}\text { trends without } \\
\text { providing a precise } \\
\text { description of how } \\
\text { to achieve them. } \\
\text { This is left to users, } \\
\text { also considering } \\
\text { that several } \\
\text { important SDGs are } \\
\text { still not covered. }\end{array}$ & & \begin{tabular}{|l|} 
knowledge gaps - \\
a key feature of \\
the tool. Limited \\
guidance is \\
provided on how \\
to develop result- \\
based initiatives.
\end{tabular} & & \begin{tabular}{|l|} 
knowledge is \\
the starting \\
point of further \\
analysis which \\
might be used \\
to develop \\
actionable \\
knowledge.
\end{tabular} & & $\begin{array}{l}\text { not address the } \\
\text { content of initiatives } \\
\text { and policies. This is } \\
\text { left to local decision } \\
\text { makers. }\end{array}$ & & $\begin{array}{l}\text { on how to pursue } \\
\text { different goals is } \\
\text { developed based on } \\
\text { local knowledge not } \\
\text { provided by the } \\
\text { tool. }\end{array}$ \\
\hline $\begin{array}{l}\text { 4. Tool is } \\
\text { flexible and } \\
\text { adaptable to } \\
\text { the } \\
\text { characteristi } \\
\text { cs of each } \\
\text { case }\end{array}$ & $\begin{array}{c}\text { RATHER } \\
\text { YES }\end{array}$ & $\begin{array}{l}\text { It can be applied to } \\
\text { different case studies } \\
\text { at national or global } \\
\text { level with minimal } \\
\text { adaptation required. } \\
\text { For other types of } \\
\text { cases, at subnational } \\
\text { level, it requires } \\
\text { "some investments". }\end{array}$ & NOT & $\begin{array}{l}\text { Can be adapted to } \\
\text { specific cases but } \\
\text { the process is not } \\
\text { simple. Adaptation } \\
\text { to new cases is a } \\
\text { task as complex and } \\
\text { demanding as } \\
\text { model development } \\
\text { requiring several } \\
\text { years. }\end{array}$ & VERY & $\begin{array}{l}\text { It does not need } \\
\text { to be adapted to } \\
\text { assess different } \\
\text { cases, types of } \\
\text { organisations or } \\
\text { scales. However, } \\
\text { it is not suitable } \\
\text { for use at } \\
\text { individual level. }\end{array}$ & POTENTI & \begin{tabular}{l|} 
No need to \\
adapt the tool. \\
Data availability \\
is the main \\
limitation \\
hindering \\
application to \\
new cases.
\end{tabular} & VERY & $\begin{array}{l}\text { It can be easily } \\
\text { applied to different } \\
\text { case studies. }\end{array}$ & YES & $\begin{array}{l}\text { Data and literature } \\
\text { availability are the } \\
\text { only limitations to } \\
\text { application. } \\
\text { Literature about } \\
\text { causal mechanisms } \\
\text { can be } \\
\text { complemented by } \\
\text { other sources }\end{array}$ \\
\hline $\begin{array}{l}\text { 5. Tool is } \\
\text { transparent } \\
\text { - logic, } \\
\text { assumptions } \\
\text {, uncertainty } \\
\text { and } \\
\text { limitations } \\
\text { are clearly } \\
\text { described }\end{array}$ & VERY & $\begin{array}{l}\text { Model assumptions, } \\
\text { limitations and } \\
\text { uncertainties are all } \\
\text { clearly described in } \\
\text { ways easily accessible } \\
\text { by users. While a user } \\
\text { manual is made } \\
\text { available, the model } \\
\text { graphical interface } \\
\text { critically contributes } \\
\text { to transparency. }\end{array}$ & $\begin{array}{c}\text { FORMAL } \\
\text { LY YES }\end{array}$ & $\begin{array}{l}\text { All assumptions, } \\
\text { limitations and } \\
\text { uncertainties are } \\
\text { thoroughly } \\
\text { illustrated in } \\
\text { manuals and } \\
\text { results. Yet, } \\
\text { transparency is for } \\
\text { developers since } \\
\text { decision makers are } \\
\text { not able and/or } \\
\text { interested. } \\
\end{array}$ & VERY & \begin{tabular}{|l|} 
Transparency \\
linked to the \\
simplicity of the \\
tool, which entails \\
no calculations or \\
assumptions. The \\
online manual \\
provides all \\
important details \\
in a few lines.
\end{tabular} & RATHER & $\begin{array}{l}\text { Application is } \\
\text { transparent but } \\
\text { the } \\
\text { interpretation } \\
\text { of results is not } \\
\text { since it is very } \\
\text { context } \\
\text { dependent. }\end{array}$ & VERY & $\begin{array}{l}\text { SDG interactions are } \\
\text { carefully documented } \\
\text { within each case } \\
\text { study to improve } \\
\text { transparency and for } \\
\text { future reference. Tool } \\
\text { manual not available } \\
\text { yet. }\end{array}$ & YES & $\begin{array}{l}\text { The visual features } \\
\text { of the tool and the } \\
\text { simplicity of the } \\
\text { logic make the tool } \\
\text { transparent. }\end{array}$ \\
\hline $\begin{array}{l}\text { 6. Informati } \\
\text { on is } \\
\text { relevant - } \\
\text { results are } \\
\text { quantified in } \\
\text { bio-physical } \\
\text { units }\end{array}$ & YES & $\begin{array}{l}\text { Results can be } \\
\text { provided in } \\
\text { qualitative or } \\
\text { quantitative form, } \\
\text { including bio-physical } \\
\text { units. }\end{array}$ & VERY & $\begin{array}{l}\text { A key feature of } \\
\text { IMAGE and IAMs is } \\
\text { the ability to } \\
\text { quantify processes } \\
\text { in physical units. }\end{array}$ & NOT & $\begin{array}{l}\text { It allows users to } \\
\text { use quantitative } \\
\text { values for } \\
\text { application, but it } \\
\text { is not required or } \\
\text { expected. }\end{array}$ & NOT & $\begin{array}{l}\text { Results provided } \\
\text { in the form of } \\
\text { functions } \\
\text { between } \\
\text { variables. }\end{array}$ & NOT & $\begin{array}{l}\text { Results presented in } \\
\text { quantitative form but } \\
\text { not in bio-physical } \\
\text { units. }\end{array}$ & NOT & $\begin{array}{l}\text { Bio-physical value } \\
\text { are used to quantify } \\
\text { relations between } \\
\text { SDGs but not to } \\
\text { present results }\end{array}$ \\
\hline
\end{tabular}




\begin{tabular}{|c|c|c|c|c|c|c|c|c|c|c|c|c|}
\hline $\begin{array}{l}\text { 7. Informati } \\
\text { on is } \\
\text { complete - } \\
\text { results cover } \\
\text { all } \\
\text { appropriate } \\
\text { scales } \\
\text { (global, } \\
\text { national, } \\
\text { local) and } \\
\text { relevant } \\
\text { SDGs }\end{array}$ & $\begin{array}{c}\text { POTENTI } \\
\text { ALLY } \\
\text { YES }\end{array}$ & $\begin{array}{l}\text { It covers all SDGs and } \\
100+\text { indicators. } \\
\text { However, it is most } \\
\text { suited for application } \\
\text { at national/global } \\
\text { scale. Yet, if required } \\
\text { the model can be } \\
\text { adapted to focus on a } \\
\text { specific sector, or } \\
\text { geographical area. }\end{array}$ & NOT & $\begin{array}{l}\text { Normally applied at } \\
\text { global and regional, } \\
\text { rarely at national } \\
\text { level. SDG scope: } 3 \\
\text { SDGs (well- } \\
\text { covered), } 10 \text { SDGs } \\
\text { (partly), } 4 \text { SDGs (not } \\
\text { covered). Regarding } \\
\text { interactions, it } \\
\text { mainly covers those } \\
\text { between SDGs 2, 6, } \\
7,12,13,14,15, \\
\text { while the human } \\
\text { development } \\
\text { elements are not } \\
\text { covered. }\end{array}$ & YES & $\begin{array}{l}\text { No pre- } \\
\text { determined scale } \\
\text { of application - } \\
\text { any scale is } \\
\text { suitable. The logic } \\
\text { of the tool is that } \\
\text { all SDGs should be } \\
\text { addressed - yet } \\
\text { users can focus on } \\
\text { certain SDGs. }\end{array}$ & $\begin{array}{c}\text { POTENTI } \\
\text { ALLY } \\
\text { YES }\end{array}$ & $\begin{array}{l}\text { Potentially the } \\
\text { tool is suitable } \\
\text { to address all } \\
\text { SDGs and all } \\
\text { geographical } \\
\text { scales. } \\
\text { However, data } \\
\text { availability at } \\
\text { subnational } \\
\text { level is often a } \\
\text { limitation. }\end{array}$ & $\begin{array}{c}\text { RATHER } \\
\text { YES }\end{array}$ & $\begin{array}{l}\text { Suitable to address all } \\
\text { SDGs, but that is not a } \\
\text { requirement. Most } \\
\text { suitable geographical } \\
\text { scales are local and } \\
\text { regional. Since SDG } \\
\text { interactions are } \\
\text { assumed to be } \\
\text { context specific, } \\
\text { national studies are } \\
\text { not ideal and global } \\
\text { studies are not } \\
\text { meaningful. }\end{array}$ & $\begin{array}{c}\text { POTENTI } \\
\text { ALLY } \\
\text { YES }\end{array}$ & $\begin{array}{l}\text { Although it can } \\
\text { cover all SDGs, lack } \\
\text { of data and } \\
\text { literature is limiting } \\
\text { the inclusion of } \\
\text { certain indicators } \\
\text { and causal } \\
\text { connections also } \\
\text { considering the } \\
\text { time available for } \\
\text { literature review. }\end{array}$ \\
\hline $\begin{array}{l}\text { 8. Informati } \\
\text { on is } \\
\text { accurate - } \\
\text { results are } \\
\text { accurate and } \\
\text { precise }\end{array}$ & RATHER & $\begin{array}{l}\text { Accuracy and } \\
\text { precision are not the } \\
\text { goals of modelling } \\
\text { with iSDG, which } \\
\text { seeks to understand } \\
\text { system dynamics. } \\
\text { Accuracy is promoted } \\
\text { through structure and } \\
\text { output behaviours } \\
\text { validation. SD models } \\
\text { conventionally } \\
\text { require that the right } \\
\text { outputs are generated } \\
\text { for the right reasons. }\end{array}$ & RATHER & $\begin{array}{l}\text { IMAGE provides } \\
\text { long term } \\
\text { projections, not } \\
\text { forecasts, and thus } \\
\text { accuracy plays a } \\
\text { different role. The } \\
\text { model is calibrated } \\
\text { and validated } \\
\text { against historical } \\
\text { data, but accuracy } \\
\text { and precision of } \\
\text { forecasts is not a } \\
\text { goal. }\end{array}$ & NOT & \begin{tabular}{|l|} 
Results are not \\
validated. \\
Accuracy is not a \\
concern under the \\
assumption that \\
sustainable \\
development is a \\
complex \\
endeavour not \\
dependent on the \\
accuracy of the \\
knowledge used \\
for decision \\
making.
\end{tabular} & VERY & \begin{tabular}{|l|} 
For this tool, \\
accuracy \\
interpreted as \\
the validity and \\
replicability of \\
the past is vital. \\
Also precision of \\
results is \\
important.
\end{tabular} & NOT & $\begin{array}{l}\text { Accuracy and } \\
\text { precision are not a } \\
\text { concern. Can expert } \\
\text { knowledge accuracy } \\
\text { be assessed? } \\
\text { Although knowledge } \\
\text { of interactions is } \\
\text { assumed to be very } \\
\text { context specific, } \\
\text { quantitative, } \\
\text { statistical knowledge } \\
\text { is being used within } \\
\text { the tool application to } \\
\text { improve the } \\
\text { objectivity of the } \\
\text { analysis. }\end{array}$ & YES & $\begin{array}{l}\text { Although precision } \\
\text { is not an ambition } \\
\text { of the tool, it is } \\
\text { important when } \\
\text { SDG interactions are } \\
\text { quantified } \\
\text { employing statistical } \\
\text { methods and } \\
\text { historical data. }\end{array}$ \\
\hline
\end{tabular}




\section{List of references}

BARBIER, E. B. \& BURGESS, J. C. 2017. The Sustainable Development Goals and the systems approach to sustainability. Economics: The Open-Access, Open-Assessment E-Journal, 11, 1-23.

COLLSTE, D., PEDERCINI, M. \& CORNELL, S. E. 2017. Policy coherence to achieve the SDGs: using integrated simulation models to assess effective policies. Sustainability science, 12, 921-931.

DÖRGŐ, G., SEBESTYÉN, V. \& ABONYI, J. 2018. Evaluating the interconnectedness of the sustainable development goals based on the causality analysis of sustainability indicators. Sustainability, 10, 3766.

DOS SANTOS, H. T. M. \& BALESTIERI, J. A. P. 2018. Spatial analysis of sustainable development goals: a correlation between socioeconomic variables and electricity use. Renewable and Sustainable Energy Reviews, 97, 367-376.

GRUBLER, A., WILSON, C., BENTO, N., BOZA-KISS, B., KREY, V., MCCOLLUM, D. L., RAO, N. D., RIAHI, K., ROGEL, J. \& DE STERCKE, S. 2018. A low energy demand scenario for meeting the $1.5 \mathrm{C}$ target and sustainable development goals without negative emission technologies. Nature energy, 3, 515-527.

GUIJARRO, F. \& POYATOS, J. A. 2018. Designing a sustainable development goal index through a goal programming model: The Case of EU-28 Countries. Sustainability, 10, 3167.

LE BLANC, D. 2015. Towards integration at last? The sustainable development goals as a network of targets. Sustainable Development, 23, 176-187.

NEUMANN, K., ANDERSON, C. \& DENICH, M. 2018. Participatory, explorative, qualitative modeling: Application of the iMODELER software to assess trade-offs among the SDGs. Economics: The Open-Access, OpenAssessment E-Journal, 12, 1-19.

NILSSON, M., GRIGGS, D. \& VISBECK, M. 2016. Policy: map the interactions between Sustainable Development Goals. Nature News, 534, 320.

SPAISER, V., RANGANATHAN, S., SWAIN, R. B. \& SUMPTER, D. J. 2017. The sustainable development oxymoron: quantifying and modelling the incompatibility of sustainable development goals. International Journal of Sustainable Development \& World Ecology, 24, 457-470.

XIN, Z. \& MOINUDDIN, M. 2017. Sustainable Development Goals Interlinkages and Network Analysis: A practical tool for SDG integration and policy coherence, Institute for Global Environmental Strategies.

ZHANG, Q., PROUTY, C., ZIMMERMAN, J. B. \& MIHELCIC, J. R. 2016. More than target 6.3: a systems approach to rethinking sustainable development goals in a resource-scarce world. Engineering, 2, 481-489. 


\section{Survey of knowledge users (English version)}

\section{Start of Block: Introduction}

Q1 This survey asks how tools intended to help decision makers to take action towards meeting the UN 2030 Agenda for Sustainable

Development can best inform decisions on the trade-offs and synergies between Sustainable Development Goals (SDGs)

The implementation of the UN 2030 Agenda requires unprecedented transformational change in all sectors of society. Knowledge of the tradeoffs and synergies between SDGs is important to decision makers, and a variety of tools have been developed using different approaches and methods to inform private and public decisions.

This survey aims to collect inputs from private and public decision makers on the features of tools that are considered most important to support decisions within companies, public authorities and civil society organisations.

The survey is part of the project OPTIMISM (Opportunities for Climate Mitigation and Sustainable Development) funded by FORMAS and NERC in the UK under the grant agreement no. NE/S012834/1.

The survey should take less than 10 minutes.

Participation consent Your survey responses will be anonymised and treated confidentially in line with the respective EU regulation. You always have the option to revoke your consent to participate in this survey or to have your stored data deleted. In these cases, please send an email to [l.di-lucia@imperial.ac.uk].

\section{Consent}

\section{Q2 Which of the following best describes your organisation:}

Business

NGO, platform or network

Academia

Government - city level

Government - regional level

Government - national level

Public agency

Othe

\section{Q3 What is your position within your organisation?}


Q4 What is the number of employees in your organisation?

$<50$

$50-250$

$250-1000$

$1000-20000$

$>20000$

Q5 To what extent have you been working with the 2030

Agenda? Select all relevant answers

I was involved in the development of the SDGs

I am directly involved in decisions relevant to the SDGs within my organisation

I provide knowledge of SDGs within my organisation

I provide knowledge of SDGs to other organisations

I am interested in the SDGs as a research topic

Others (please insert text below) 
Q31 Which SDGs do you consider (directly or indirectly) in your work?

\author{
$\square$ SDG 1 - No poverty \\ SDG 2 - Zero hunger \\ SDG 3 - Good health and well-being \\ SDG 4 - Quality education \\ SDG 5 - Gender equality \\ SDG 6 - Clean water and sanitation \\ SDG 7 - Affordable and clean energy \\ SDG 8 - Decent work and economic growth \\ SDG 9 - Industry innovation and infrastructure \\ SDG 10 - Reduced inequalities \\ SDG 11 - Sustainable cities and communities \\ SDG 12 - Responsible consumption and production \\ SDG 13 - Climate action \\ SDG 14 - Life below water
}


SDG 15 - Life on land

SDG 16 - Peace, justice and strong institutions

SDG 17 - Partnerships for the goals

All

\section{Q7 What is your gender?}

\author{
Female \\ Male \\ Prefer not to say
}

\section{Q8 What is your age group?}
$20-29$
$30-39$
$40-49$
$50-59$
$>60$

\section{Start of Block: MaxDiff}

QA The following questions refer to the tools required to provide knowledge of SDGs interactions to decision makers working on the implementation of the Agenda

We would like to know which features you believe are most important in helping decision makers to take informed decisions about the interactions between SDGs

For each pair of statements, please select the issue that you consider most important based on your experience

\section{Q9a Select the most important issue}

Information is complete - results cover all appropriate scales (global, national, local) and relevant SDGs (1)

Information is accurate - results are accurate and precise (2) 


\section{Q9b Select the most important issue}

Information is actionable - results directly support and inform evidence-based decisions

Information is relevant - results are quantified in bio-physical units

\section{Q9c Select the most important issue}

Information is understandable - results can be interpreted

Tool is flexible and adaptable to the characteristics of each case

\section{Q9d Select the most important issue}

Tool is transparent - logic, assumptions, uncertainties and limitations are clearly described

Tool is easy to use - time, cost and effort requirements for application

\section{Q9e Select the most important issue}

Information is complete - results cover all appropriate scales (global, national, local) and relevant SDGs

Information is actionable - results directly support and inform evidence-based decisions

\section{Q9f Select the most important issue}

Information is accurate - results are accurate and precise

Information is relevant - results are quantified in bio-physical units

\section{Q9g Select the most important issue}

Information is understandable - results can be interpreted without specialist knowledge

Tool is transparent - logic, assumptions, uncertainties and limitations are clearly described 


\section{Q9h Select the most important issue}

Tool is flexible and adaptable to the characteristics of each case

Tool is easy to use - time, cost and effort requirements for application

\section{Q9j Select the most important issue}

Information is complete - results cover all appropriate scales (global, national, local) and relevant SDGs

Tool is easy to use - time, cost and effort requirements for application

\section{Q9 Select the most important issue}

Information is accurate - results are accurate and precise

Information is actionable - results directly support and inform evidence-based decisions

\section{Q10 Select the most important issue}

Tool is easy to use - time, cost and effort requirements for application

Information is understandable - results can be interpreted without specialist knowledge

\section{Q11 Select the most important issue}

Tool is flexible and adaptable to the characteristics of each case

Tool is transparent - logic, assumptions, uncertainties and limitations are clearly described

\section{Q12 Select the most important issue}

Information is understandable - results can be interpreted without specialist knowledge

Information is complete - results cover all appropriate scales (global, national, local) and relevant SDGs 


\section{Q13 Select the most important issue}

Tool is flexible and adaptable to the characteristics of each case

Information is accurate - results are accurate and precise

\section{Q14 Select the most important issue}

Tool is transparent - logic, assumptions, uncertainties and limitations are clearly described

Information is actionable - results directly support and inform evidence-based decisions

\section{Q15 Select the most important issue}

Tool is easy to use - time, cost and effort requirements for application

Information is relevant - results are quantified in bio-physical units

\section{End of Block: MaxDiff}

Start of Block: MaxDiff 1

QB Keep going! A few more questions to go

\section{Q16 Select the most important issue}

Information is complete - results cover all appropriate scales (global, national, local) and relevant SDGs

Tool is flexible and adaptable to the characteristics of each case

\section{Q17 Select the most important issue}

Information is accurate - results are accurate and precise

Information is understandable - results can be interpreted without specialist knowledge

\section{Q18 Select the most important issue}

Information is actionable - results directly support and inform evidence-based decisions

Tool is easy to use - time, cost and effort requirements for application 


\section{Q19 Select the most important issue}

Information is relevant - results are quantified in bio-physical units

Tool is transparent - logic, assumptions, uncertainties and limitations are clearly described

\section{Q20 Select the most important issue}

Tool is transparent - logic, assumptions, uncertainties and limitations are clearly described

Information is complete - results cover all appropriate scales (global, national, local) and relevant SDGs

\section{Q21 Select the most important issue}

Tool is easy to use - time, cost and effort requirements for application

Information is accurate - results are accurate and precise

\section{Q22 Select the most important issue}

Information is actionable - results directly support and inform evidence-based decisions

Information is understandable - results can be interpreted without specialist knowledge

\section{End of Block: MaxDiff 1}

\section{Start of Block: MaxDiff 2}

QC Almost there! last 5 questions

\section{Q23 Select the most important issue}

Information is relevant - results are quantified in bio-physical units

Tool is flexible and adaptable to the characteristics of each case (

\section{Q24 Select the most important issue}

Tool is easy to use - time, cost and effort requirements for application

Information is complete - results cover all appropriate scales (global, national, local) and relevant SDGs 


\section{Q25 Select the most important issue}

Information is accurate - results are accurate and precise

Tool is transparent - logic, assumptions, uncertainties and limitations are clearly described

\section{Q26 Select the most important issue}

Information is actionable - results directly support and inform evidence-based decisions

Tool is flexible and adaptable to the characteristics of each case

\section{Q27 Select the most important issue}

Information is relevant - results are quantified in bio-physical units

Information is understandable - results can be interpreted without specialist knowledge

Q32 Is there any comment you would like to add that could improve the design of tools? 